\title{
Effects of castration on the expression of the NGF and TrkA in the vas deferens and accessory male genital glands of the rat
}

\author{
C. Squillacioti, ${ }^{1}$ A. De Luca, ${ }^{1}$ S. Paino, ${ }^{2}$ E. Langella, ${ }^{2}$ N. Mirabella ${ }^{1}$ \\ ${ }^{1}$ Department of Structures, Functions and biological Technologies - University of Naples "Federico II"; \\ ${ }^{2}$ Department of Sciences of animal productions, Università della Basilicata, Potenza, Italy
}

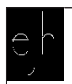

(C)2009 European Journal of Histochemistry

Nerve Growth Factor (NGF) is a member of the neurotrophin family. Neurotrophins exert their effects by binding to corresponding receptors, which are formed by the tyrosine protein kinases TrkA, TrkB, and TrkC, and the low affinity p75NTR receptor. The role of neurotrophins in the biology of male genital organs is far from clear. In particular, little is known about the influence of sex hormones on the expression of neurotrophins and their receptors. In the present study, using immunohistochemistry and real time RT-PCR, we investigated the expression of NGF and TrkA in the vas deferens and accessory male genital glands in normal and castrated rats.

In normal rats, both NGF- and TrkA-immunoreactivities (IR) were localized in the epithelial layer of the vas deferens. NGFIR was also found in the stroma and epithelium of the vesicular gland and prostate. TrkA-IR was distributed in the epithelial cells of vesicular and prostate glands. The nerves were weakly immunoreactive in all the examined organs. After castration the immunoreactivities increased. Real-time RT-PCR experiments indicated that NGF and TrkA mRNA levels increased significantly after castration. These results suggest that NGF and TrkA are expressed in the internal male genital organs of the rat and that their expression is downregulated by androgen hormones. We hypothesize NGF and TrkA play a role in the processes that regulate the involution of these organs under conditions of androgen deprivation.

Key words: androgen hormones, stromal cells, immunohistochemistry, real-time RT-PCR, prostate.

Correspondence: Caterina Squillacioti,

Department of Structures, Functions and biological Technologies, University of Naples "Federico II", Via Veterinaria 1, Naples, 80137, Italy

Tel.: +39.081.2536113.

Fax: +39.081.2536097.

E-mail: caterina.squillacioti@unina.it

Paper accepted on October 6, 2009

European Journal of Histochemistry 2009; vol. 53 issue 4 (October-December): 239-248
$\mathrm{N}$ erve growth factor (NGF) is a member of the neurotrophin family, a family of neurotrophic factors that also includes Brainderived neurotrophic factor (BDNF), neurotrophin 3 (NT3) and neurotrophins 4/5 (NT4/5). Neurotrophins have essential roles in the survival, development and differentiation of neurons in the central and peripheral nervous systems (LeviMontalcini, 1987; Ernfors et al., 1994; Snider, 1994; Barbacid, 1995; Huang and Reichart, 2001; Murer et al., 2001). Furthermore, recent data show that neurotrophins are involved in a variety of biological processes in nonneuronal tissues (Yamamoto et al., 1996; Sariola, 2001; Leon et al., 1994; Rosenbaum et al., 1998; Tessarollo, 1998). The biological effects of neurotrophins are mediated by tyrosine kinase receptors encoded by the trk protooncogene family, known as TrkA, TrkB and TrkC (Barbacid, 1995; Lewin and Barde, 1996; Patapoutian and Reichart, 2001). The Trk receptors are specific for their ligands; NGF is the preferred ligand for TrkA, BDNF and NT-4/5 are preferred ligands for TrkB and NT-3 is the preferred ligand for TrkC. In addition, all neurotrophins are recognized by a more widely expressed low-affinity receptor known as panneurotrophinreceptor p75NTR, which is a member of the tumor necrosis factor (TNF) receptor family (Teng \& Hempstead, 2004).

The presence of neurotrophins in the accessory male genital tissues has been well documented. NGF and large quantities of NGF have been found in the vesicular and prostate glands and are related to the rich sympathetic innervation of these organs (Harper et al., 1979, 1982; Harper and Thoenen, 1980; Hofmann and Unsicker, 1982).

NGF and its receptors (TrkA, p75NTR) have been immunohistochemically expressed in the reproductive organs of the adult male rats ( $\mathrm{Li}$ et 
al., 2005). In the prostate, NGF and NGF precursor have been immunohistochemically localized in the glandular epithelium, suggesting that secretory epithelial cells are the site of production of this factor (Shikata et al., 1984; MacGrogan et al., 1991; Paul et al., 1996). Paracrine neurotrophin synthesis by stromal cells has also been postulated (Pflug et al,. 1995; Dalal and Djakiew, 1997; Weeraratna et al., 2000). High- and low-affinity neurotrophin receptors have been recognized in the nerves and epithelial cells of the prostate (Weeraratna et al., 2000; Graham et al., 1992; MacGrogan et al., 1992; Paul and Habib, 1998; Guate et al., 1999), thus indicating that neurotrophins play a role as growth-regulating factors in this gland.

The exact role of neurotrophins in the biology of male genital organs, however, is far from clear. Recently, in the vas deferens and accessory male genital glands of the rat, the expression of the BDNF and its receptors (TrkB and p75NTR) has been reported to be regulated by androgen hormones (Mirabella et al., 2006; Mirabella et al., 2008). In castrated rats, moreover, BDNF has been hypothesized to regulate, via interacting p75NTR, the castration-induced regression of the sympathetic innervation (Mirabella et al., 2006).

The present study has, therefore, been undertaken to elucidate the presence and localization of NGF and TrkA in the vas deferens and accessory male genital glands of the rat. In addition, the expression of these proteins and their mRNAs have been determined after castration in order to evaluate whether this neurotrophin and its specific receptor are under the control of androgens.

\section{Materials and Methods}

\section{Rats, surgery and tissue removal}

A total of 30 adult male Sprague-Dawley rats (13 weeks of age; body weight: $380 \pm 20$ g; purchased from Harlan Italy) were used. They were housed in temperature- and light-controlled rooms and were given water ad libitum. Rats received humane care and the study protocol was in compliance with our institution's ethical guidelines. All procedures were approved by Italian laws regarding animal use in research (art. 7 D.Lgs. 116/92). Fifteeen rats were left intact and served as controls. Fifteen rats were castrated at 9 weeks of age (body weight: $300 \pm 20 \mathrm{~g}$ ) and allowed to recover over the following 4 weeks. All surgical procedures were carried out aseptically under anaesthesia induced with urethane $(1.2 \mathrm{~g} / \mathrm{kg})$. Vas deferens, vesicular and coagulating glands and dorsal and ventral prostate were removed from normal (control) and castrated rats after they had been anaesthetized and then killed. Specimens from five normal and five castrated rats were used for immunohistochemistry. Each specimen collected from the remaining ten castrated and ten intact rats was used for real-time reverse transcription/polymerase chain reaction (real-time $\mathrm{RT} / \mathrm{PCR}$ ) procedures.

\section{Immunohistochemistry}

The specimens were immediately fixed by immersion in Bouin's fixative (6-24 h), processed for paraffin embedding in vacuum and cut at a thickness of 5-7 $\mu \mathrm{m}$. The avidinbiotin- peroxidase complex $(A B C)$ method was performed with the Vectastain ABC kit (Vector Laboratories, Burlingame, Calif., USA). Sections were deparaffinized in xylene and hydrated in a graded solution of ethanol. After the quenching of endogenous peroxidase activity in water containing $0.3 \%$ hydrogen peroxide for $30 \mathrm{~min}$, nonspecific binding was blocked by treatment with $1.5 \%$ normal goat serum (Vector) in $0.01 \mathrm{M} \mathrm{PBS}$ (phosphate buffered saline; $\mathrm{pH}$ 7.2) for $30 \mathrm{~min}$. Polyclonal rabbit anti-NGF (sc-549; Santa Cruz Biotechnology, Santa Cruz, CA, USA), and-Trk A (sc-118; Santa Cruz Biotechnology, Santa Cruz, CA, USA) were singularly applied to the sections at a dilution of 1:500 and each specimen was incubated in a moist chamber overnight at $4^{\circ} \mathrm{C}$. After the sections had been washed three times in PBS, biotinylated anti-rabbit IgG (Vector) was applied at a dilution of 1:200. The sections were again incubated for $30 \mathrm{~min}$ at room temperature. Freshly prepared $A B C$ reagent (Vector) was applied and incubated for $30 \mathrm{~min}$ after three washes in PBS. The localization of NGF- and TrkA-immunoreactivities were visualized by incubating the sections for 5 min in freshly prepared diaminobenzidine-nickel solution (Vector). The specificity of the immunoreactions was tested by replacing the primary antibody with buffer. No immunoreaction was detected in control tests. The specificity of the primary antibody anti-NGF and anti-TrkA were tested by adsorption the primary 
antibody with excess (up to $50 \mu \mathrm{g} / \mathrm{mL}$ in the final dilution) homologous antigen peptide (NGF peptide sc-549P; TrkA peptide sc-118P Santa Cruz Biotechnology). Five slides for each rat and for each control or castrated tissue were independently evaluated by two observers by using a Leica DMRA2 microscope.

\section{RNA extraction and CDNA synthesis}

RNA extraction was prepared from tissues collected from normal $(n=10)$ and castrated $(n=10)$ rats. Fresh tissues were immediately frozen on dry ice and stored at $-80^{\circ} \mathrm{C}$ until extraction. Total RNA from tissues was prepared by using TRIreagent (Sigma, St Louis, Mo., USA) according to the manufacturer's protocol. Complementary DNA was synthesized with the cMaster RT kit (Eppendorf, Westbury, New York, USA) and random hexamers as primer.

\section{Real-time RT-PCR}

Primers specific for rat NGF and TrkA were designed from the published gene sequences (NGF gene,Genbank, XM227525; TrkA gene, Genbank, NM 021589) using the Primer Express $^{\text {TM }}$ software (PE Applied Biosystems). The sense and anti-sense NGF primers used were $5^{\prime}$ TGC ATA GCG TAA TGT CCA TGT TG-3' and 5'CTG TGT CAA GGG AAT GCT GAA -3', respectively, which amplify a 148-bp fragment. The sense and anti-sense TrkA primers used were 5'-CAT GAC ACT GGG TGG CAG TT -3 ' and 5'-TCC CCT AGC TCC CAC TTG AGA -3', respectively, which amplify a 149-bp fragment.

The sense and antisense Actin primers used were 5'- CGT GAC ATT AAA GAG AAG CTG TGC-3' and 5'-TAG TTT CAT GGA TGC CAC AGG AT -3', respectively, which amplify a 205-bp fragment (Genbank, NM 031144)

The PCR conditions were $50^{\circ} \mathrm{C}$ for $2 \mathrm{~min}$ and $94^{\circ} \mathrm{C}$ for $10 \mathrm{~min}$, followed by 40 cycles of $94^{\circ} \mathrm{C}$ for $15 \mathrm{~min}$ and $60^{\circ} \mathrm{C}$ for $1 \mathrm{~min}$. PCRs contained 1 $\mu \mathrm{L}$ cDNA (40 ng/well), $24 \mu \mathrm{L}$ of Master Mix Sybr Green (Applied Biosystems) containing specific primers. A sample without cDNA template was used to verify that the master mix was free from contaminants. The samples were performed in triplicate. The $\beta$-Actin gene was also amplified in separate tubes under the same conditions as an active endogenous reference to normalize quantification of mRNA target. Real-time PCRs for target and reference genes were run in the same $\mathrm{RT}$ reaction Real-time detection was performed on an ABIPRISM 7300 Sequence Detection System (Applied Biosystems) and data from SYBR Green I PCR amplicons were collected with ABI 7300 System SDS Software.The fluorescence signal baseline and threshold were set manually for each detector (NGF, TrkA, $\beta$-actin), generating a threshold cycle (Ct) for each sample. An amplification plot graphically displayed the fluorescence detected over the number of cycles that were performed. Standard curves for both targets and the endogenous reference gene, created on the basis of the linear relationship between the $\mathrm{Ct}$ value and the logarithm of the starting amount of cDNA, showed acceptable slope values (included between -3.8 and -3.3 ). Standard curves were obtained by using serial dilutions of sample cDNA $(1: 2,1: 4$, $1: 8,1: 16,1: 32$ ).

Relative quantification method 2-[Delta][Delta] Ct ( $\left.2^{\text {-delta delta ct }}\right)$ was used for normalization of gene expression (Huggett et al., 2005; Livak and Schmittgen, 2001; Yuan et al., 2006;) Before using the $\Delta \Delta \mathrm{Ct}$ method for relative quantification (comparative method), a validation experiment was required in order to demonstrate that the efficiency of the target amplification and that of the reference amplification were almost equal. All PCR efficiencies were measured and found to be adequate (slope $<0.1$ ).

The difference between $\mathrm{Ct}$ values was calculated for each mRNA by taking the mean Ct of triplicate reactions and subtracting the mean $\mathrm{Ct}$ of triplicate reactions for the reference RNA measured on an aliquot from the same $\mathrm{RT}$ reaction

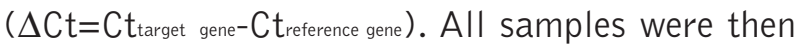
normalized to the $\Delta C t$ value of a calibrator sample to obtain a $\Delta \Delta \mathrm{Ct}$ value ( $\Delta \mathrm{C} \mathrm{t}_{\text {target}}-\Delta \mathrm{C} \mathrm{t}_{\text {calibrator }}$ ).

The calibrator, defined as the sample used as the basis for comparative results, could represent an untreated control i.e normal rats. Normal rats were chosen as calibrators. For the comparative method, relative quantifications were calculated in relation to the concentrations of the calibrator sample $\left(2^{-\Delta \Delta c t}\right)$, expressed in arbitrary units and normalized to the endogenous reference gene ( $\beta$ actin).

Therefore, by using the $2^{-\Delta \Delta c t}$ method, data were recorded as the fold-change in gene expression normalized with the endogenous reference gene and relative to the calibrator sample (Huggett et 
al., 2005; Livak and Schmittgen, 2001). Dissociation melting curves confirmed the specific amplification of the cDNA target and the absence of nonspecific products.

The results are represented as mean $( \pm S E M)$ of triplicate determinations for each tissue and from each experimental animal .

For statistical analysis, the data were expressed as the mean \pm standard error. Significant differences in NGF and TrkA mRNA levels between the calibrator sample (normal rats) vs castrated rats were determined by using Student's t-test for independent samples. The level of statistical significance was set at $p<0.05$ for all.

\section{Results}

\section{Immunohistochemistry}

The results of NGF and TrkA immunoreactivities are summarized in Table 1.

\section{NGF-immunoreactivity}

In the vas deferens of normal rats (Figure $1 a$ ), NGF-IR was found in the ductal epithelium. After castration (Figure 1 b), the immunoreactivity persisted in the epithelium in which it was confined to the apical border of epithelial cells. In the vesicular gland of normal rats (Figure 1c), NGF-IR was prevalently localized in the fibromuscular cells. After castration (Figure 1d), NGF-IR increased in the fibromuscular cells. In both the dorsal and ventral (Figure le, h) normal prostatic lobes, NGF-IR was found in the stroma surrounding the tubuloalveoli. In the stroma, immunoreactivity was localized in elongated spindle-shaped fibromuscular cells. In only few cases NGF-IR was found in epithelial cells (Figure If). After castration (Figure 1g, i), NGF-IR increased in the stromal tissue. The nerves were weakly immunoreactive in all the examined organs (data not shown).

\section{TrkA-immunoreactivity}

In the vas deferens of normal rats (Figure 2a), TrkA-IR was found in the columnar secretory cells of the ductal epithelium. After castration (Figure $2 b)$, the immunoreactivity persisted in the epithelial cells. In the vesicular gland of normal rats (Figure $2 c, d$ ) TrkA-IR was located in secretory epithelial cells. After castration immunoreactivity increased in the secretory epithelial cells (Figure $2 e$ ). In both the dorsal (Figure 2f) and ventral (Figure $2 \mathrm{~h}$ ) prostatic lobes, TrkA-IR was observed in basal cells of the alveolar epithelium. Cells expressing TrkA were flat or cubical and located at the epithelial- stromal junction and did not reach the lumen of the alveoli. After castration (Figure $2 \mathrm{~g}, \mathrm{~h}$ ) immunoreactivity increased in the basal cells.

\section{Real-time RT-PCR}

Real-time RT-PCR experiments showed that the level of NGF mRNA expression increased significantly in the vesicular gland and dorsal and ven-

Table 1. Distribution of NGF (a) and TrkA (b) immunoreactivities in the vas deferens and accessory male sex glands of normal and castrated rats (b.e.c. basal epithelial cells, s.e.c. secretory epithelial cells, $n$. nerves, f.s.c. fibromuscular stromal cells + low density, ++ medium density, +++ high density).

a)

\begin{tabular}{|c|c|c|c|c|c|c|c|c|}
\hline & \multicolumn{2}{|c|}{ Vas deferens } & \multicolumn{2}{|c|}{ Vesicular gland } & \multicolumn{2}{|c|}{ Dorsal prostate } & \multicolumn{2}{|c|}{ Ventral prostate } \\
\hline & normal & castrated & normal & castrated & normal & castrated & normal & castrated \\
\hline \multicolumn{9}{|l|}{ b.e.c. } \\
\hline s.e.c. & ++ & ++ & & & + & + & + & + \\
\hline f.s.c. & & & + & ++ & ++ & +++ & ${ }^{++}$ & ${ }^{+++}$ \\
\hline $\mathrm{n}$. & + & + & + & + & + & + & + & + \\
\hline
\end{tabular}

b)

\begin{tabular}{|c|c|c|c|c|c|c|c|c|}
\hline & \multicolumn{2}{|c|}{ Vas deferens } & \multicolumn{2}{|c|}{ Vesicular gland } & \multicolumn{2}{|c|}{ Dorsal prostate } & \multicolumn{2}{|c|}{ Ventral prostate } \\
\hline & normal & castrated & normal & castrated & normal & castrated & normal & castrated \\
\hline b.e.c. & & & & & + & +++ & + & +++ \\
\hline $\begin{array}{l}\text { s.e.c. } \\
\text { f.s.c. }\end{array}$ & ++ & ++ & ++ & +++ & & & & \\
\hline n. & + & + & + & + & + & + & + & + \\
\hline
\end{tabular}



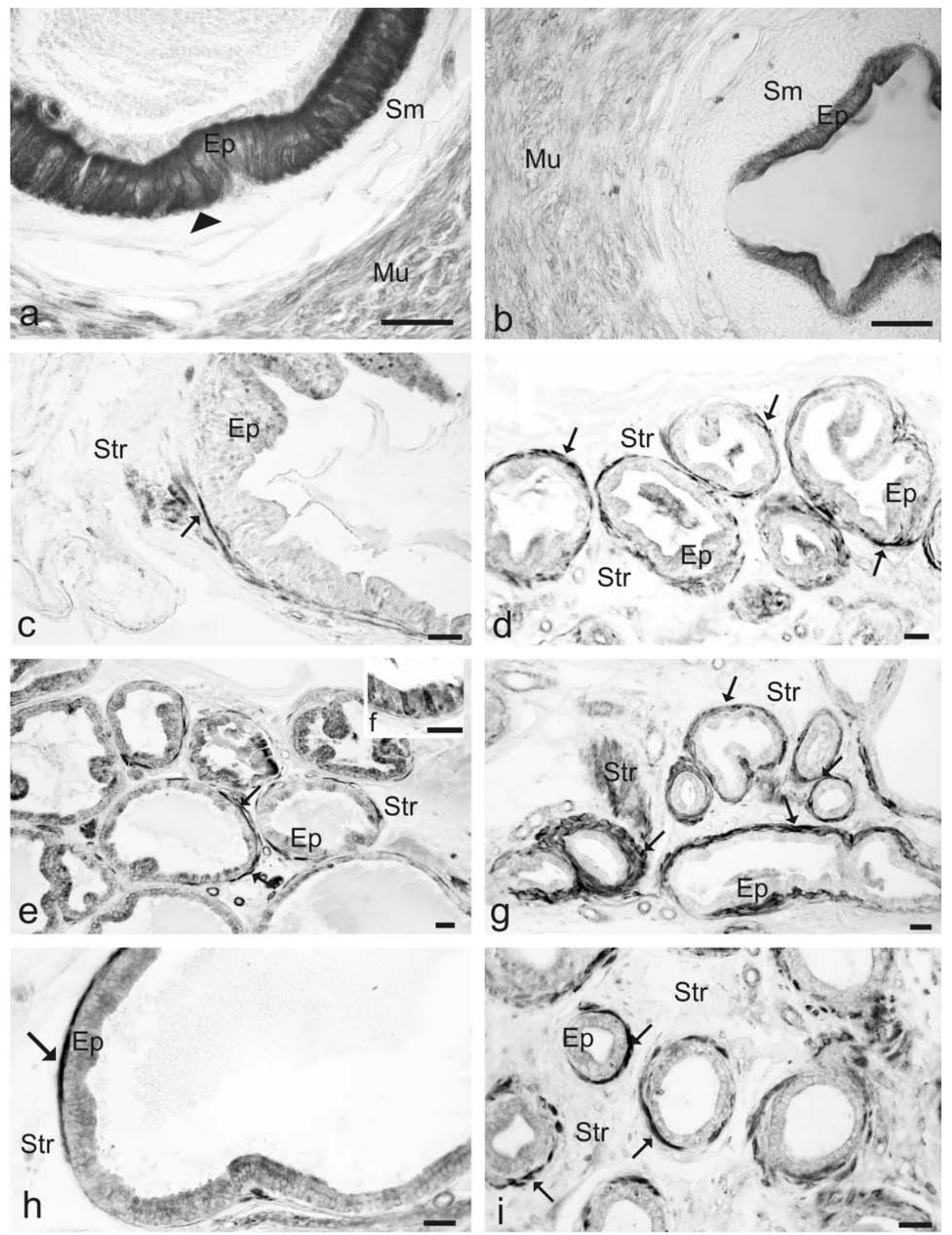

Figure 1. Distribution of NGF-immunoreactivity in the vas deferens $(a, b)$, vesicular gland $(c, d)$ and dorsal (e-g) and ventral $(\mathrm{h}, \mathrm{i})$ prostatic lobes of normal (a, c, e, f, h) and castrated rats (b, d, g, i). Ep epithelium, Mu tunica muscularis, Str stroma, Sm tela submucosa, arrow immunoreactive stromal cells, arrowheads immunoreactive epithelial cells. NGF- IR was found in the epithelium of the vas deferens (a) and glands (c, e, f, ) and in the stromal cells of the prostate (c, e, h). After castration, the immunoreactivity persisted in the epithelium and increased in the stromal cells (b, d, g, i). Scale bars $50 \mu \mathrm{m}$. 

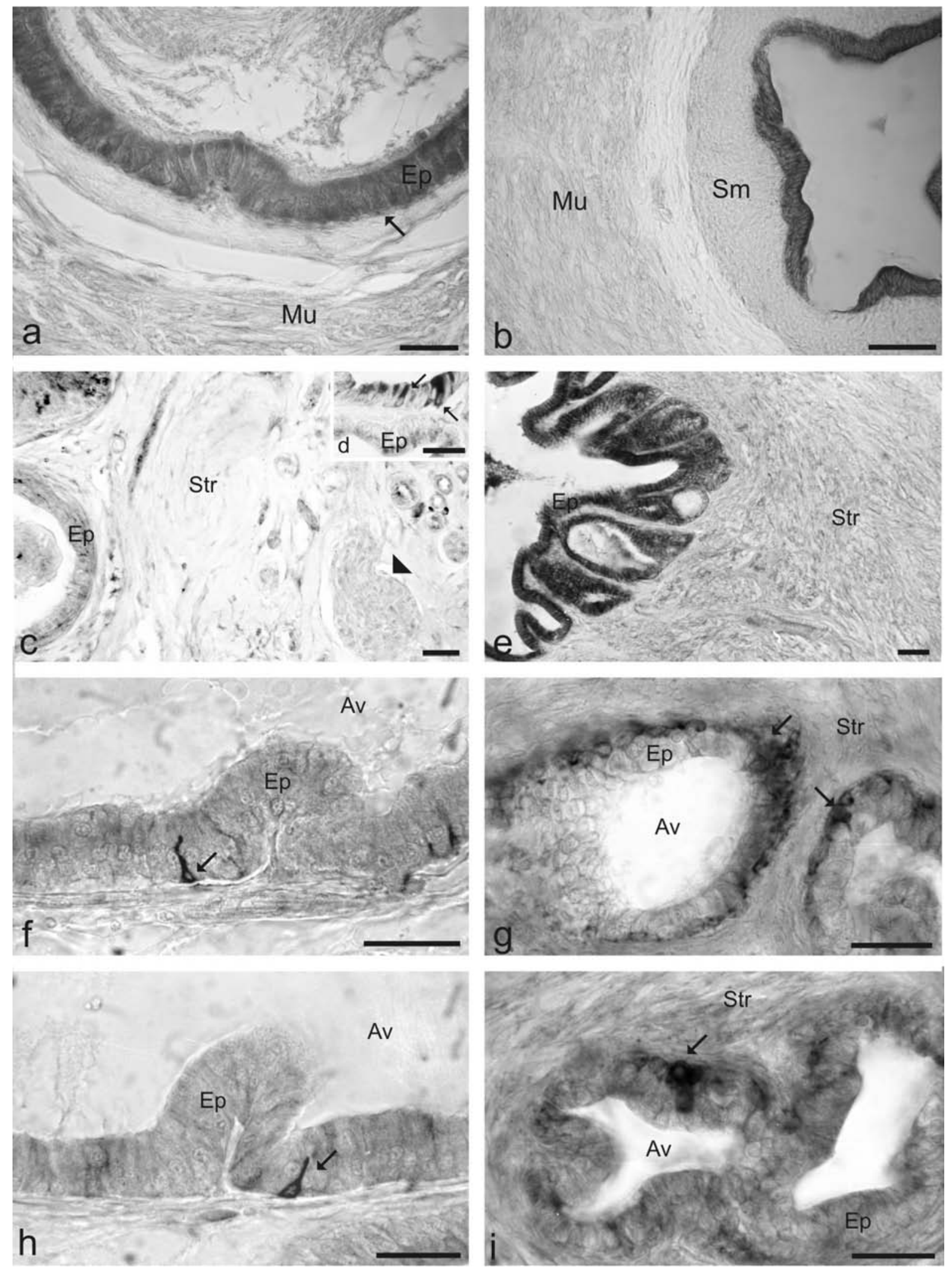

Figure 2. Distribution of TrkA-IR in the vas deferens (a, b), vesicular gland (c, $d, e)$ and dorsal $(f, g)$ and ventral (h, i) prostatic lobes of the normal (a, c, d, f, h) and castrated (b, e, g, i). Ep epithelium, Mu tunica muscularis, Str stroma, Sm tela submucosa, Av tubuloalveoli arrow immunoreactive epithelial cells, arrowheads nerves. TrkA-IR was found in the secretory epithelial cells of the vas deferens (a) and vesicular gland (c, d) and in the basal cells of the prostate (f, h). After castration the immunoreactivity persisted and it increase in the epithelium of the vas deferens( b) and glands (e, g, i). Scale bars $50 \mu \mathrm{m}$. 
tral prostatic lobes of the castrated rats (Figure 3). The level of TrkA mRNA expression also increased significantly in the vesicular gland and dorsal and ventral prostatic lobes of the castrated rats (Figure 4)

In the vas deferens, the difference in the levels of NGF and TrkA mRNA expression between castrated and normal rats were not statistically significant (Figure 3, 4).

\section{Discussion}

The results of the present study demonstrate that NGF and TrkA are expressed in the vas deferens and accessory male genital glands of the rat. The presence of mRNAs of these proteins suggests in situ synthesis of the neurotrophic factor and its receptor.

NGF-IR was distributed in the epithelium of the vas deferens and genital glands and in the stromal cells of the vesicular gland and of the prostate. In particular NGF-IR was localized in secretory epithelial cells of the vas deferens and of glands and in the fibromuscular stromal tissue of the glands. The present results are in accordance with previous reports in which NGF-IR was observed in secretory epithelial cells of the adult male rat vesicular and prostate glands ( $\mathrm{Li}$ et al., 2005), and in the Japanese monkey (Jin et al., 2006) and guinea pig prostate (MacGrogan et al., 1991; Shikata et al., 1984). These results suggest that secretory epithelial cells are the site of production of this factor (Harper et al., 1979; Shikata et al., 1984; MacGrogan et al., 1991; Paul et al., 1996). On the other hand, the localization of NGF-IR in the stromal cells of the prostate is consistent with previous findings reporting NGF-IR in cultured prostate stromal cells (Djakiew et al., 1991; Dalal and Djakiew, 1997). In addition, the localization of NGF-IR was reported in the human normal and adenocarcinoma prostate stromal tissues in vivo (Graham et al., 1992).

TrkA-IR was distributed in the epithelium of both vas deferens and glands. In particular TrkAIR was found in the secretory cells of the vesicu-
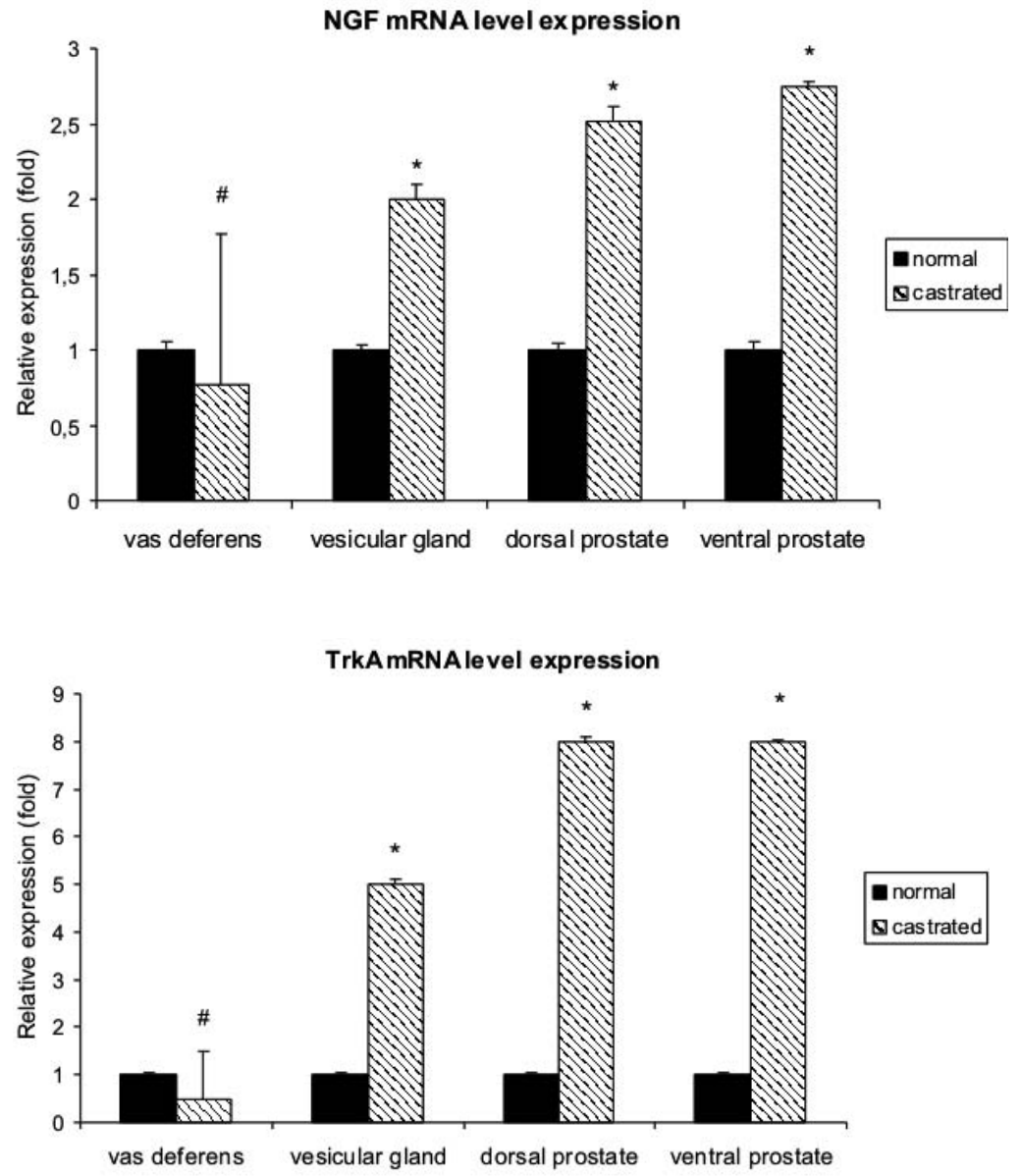

Figure 3. Expression of NGF mRNA in normal and castrated rats. Real-time RT-PCR was performed on vas deferens, vesicular gland and dorsal and ventral prostate. The data were expressed as the meantstandard error. Significant differences in NGF mRNA levels between the calibrator sample (normal rats) vs castrated rats were determined by using Student's t-test for independent samples. The level of statistical significance was set at $p<0.05$ for all. ${ }^{*}=p<0.05 ; \# p=0.10$. Note that NGF mRNA levels increase in the vesicular gland and in the dorsal and ventral prostate of the castrated rats. These results were consistent with the immunohistochemical staining results. In the vas deferens the difference was not statistically significant.

\begin{abstract}
Figure 4. Expression of TrkA mRNA in normal and castrated rats. Real-time RT-PCR was performed on vas deferens, vesicular gland and dorsal and ventral prostate. The data were expressed as the mean \pm standard error. Significant differences in TrkA mRNA levels between the calibrator sample (normal rats) vs castrated rats were determined by using Student's t-test for independent samples. The level of statistical significance was set at $p<0.05$ for all. ${ }^{*}=p<0.05$; $\# p=0.10$. Note that TrkA mRNA levels increase in the vesicular gland and in the dorsal and ventral prostate of the castrated rats. These results were consistent with the immunohistochemical staining results. In the vas deferens the difference was not statistically significant.
\end{abstract}


lar gland and in the basal cells of the prostate. These results are in accordance with previous reports, in which immunoreactivity of TrkA was observed in secretory epithelial cells of the seminal vesicles of the adult male rat ( $\mathrm{Li}$ et al., 2005) and in the basal epithelial cells of the human normal prostate (Guate et al., 1999). However, our findings disagree with those reported in the rat prostate where TrkA-IR was localized in secretory but not in basal epithelial cells ( $\mathrm{Li}$ et al., 2005). The localization of TrkA in basal epithelial cells, i.e. the proliferating cells, suggests that TrkA specific ligands might regulate cell turnover in the epithelium of the rat prostate gland. NGF-IR was observed in the stromal fibromuscular cells of the prostate gland thus suggesting that NGF produced by muscular tissues interacts via a paracrine mechanism with TrkA receptor on the adjacent basal epithelial cells in regulating epithelial cellular growth. In the prostate gland, the presence of both NGF and TrkA immunoreactivities in epithelial cells supports the hypothesis that NGF of epithelial source influences in an autocrine/ paracrine manner the cellular growth and secretory activity of the prostatic epithelium. NGF is one autocrine/paracrine factor regulating prostate function (Harper et al., 1979; Djakiew et al., 1991; Graham et al., 1992; Macgrogan et al., 1992; Paul et al., 1996). Prostatic growth and differentiation are regulated by androgens and other autocrine and paracrine factors secreted by both epithelial and stromal cells (Cunha, 1994). Alterations in these regulatory pathways may contribute to the initiation and progression of prostate cancer (Cunha, 1994; Djakiew et al., 1990; for reviews Geldof et al., 1998; Kruttgen et al., 2006).

NGF and TrkA mRNAs was also present in all the examined tissues as demonstrated by results of the real-time RT-PCR experiments. Previous studies indicated the presence of NGF mRNA in the guinea pig prostate (MacGrogan et al., 1991, 1992).

One of the aims of the present study was to evaluate if and how castration influences the expression of the NGF and TrkA in the rat vas deferens and accessory male genital glands. Castration caused an increase of NGF-IR in stromal fibromuscular cells and of TrkA-IR in epithelial cells. Moreover, the results of real-time RT-PCR demonstrated that NGF and TrkA mRNA increased in both vesicular and prostate glands in castrated rats. These results suggest that androgen hormones negatively influence the expression of NGF and its receptor in male rat accessory male genital gland tissues. In the vas deferens, although the data were not statistically significant, castration produces a decrease of NGF and TrkA mRNA level expression. This discrepancy may reflect differences occurring among male genital tissues in the regulation of NGF and its receptor expression by androgen hormones.

These results are in contrast to those reported for NGF expression in several androgen target tissues. In the guinea pig prostate, castration has been reported to have no effect on NGF mRNA expression estimated by RNA blot hybridization analysis (MacGrogan et al., 1991). In additon, NGF has been reported to be markedly upregulated by androgens in mouse brain regions (KatohSemba et al., 1994) and submandibular salivary glands (Humpel et al., 1993). However, recently, we have observed that castration induced an increase of the expression of BDNF, another member of the neurotrophin's family, in the accessory male genital glands of the rat (Mirabella et al. 2006). NGF- and TRKA-IRs were observed to be poorly distributed in the nerves, and, moreover, they were unaffected by castration. This result is in contrast to what reported for BDNF-IR (Mirabella et al., 2006) which strongly increased in the nerves after castration. The increase BDNFIR after castration was addressed to a role played by this neurotrophin in regulating the castrationinduced regression of sympathetic nerves. The increase of P75NTR-IR in the nerves after castration corroborates this hypothesis (Mirabella et al., 2008). In the present study, we have observed an increase in NGF and TrkA expression in stromal and epithelial cells but not in the nerves. These results suggest that NGF and its receptor are involved in regulating the apoptotic processes occurring in the sex gland epithelial tissue after castration rather than the regression of sympathetic nerves. This suggests that different neurotrophins play different roles in regulating the involutive processes which occurr in male genital tissues after castration.

Several studies have reported that NGF induces apoptosis in some condition rather than trophic effects. NGF-mediated apoptosis is cell-cycle dependent and NGF/TrkA signal transduction 
pathway could activate apoptotic cell death programmes in CNS neuroepithelial progenitor cells and in childhood brain tumors (Muragaki et al., 1997). In human neuroblastoma, an elevated level of TrkA mRNA was associated with increased apoptosis in tumor cells (Nakagawara et al., 1993). In rat pheochromocytoma cell line $\mathrm{PC} 12$, NGF via TrkA induces apoptosis following serum deprivation (Ahn et al.et al., 2005). Although NGF and neurotrophins are primarily known for their ability to promote the proliferation, survival and maturation of target cells, these studies suggest that NGF can be cytotoxic depending on the culture condition or nature of cell type.

In conclusion, the results of the present study have shown that the expression of NGF and TrkA are expressed in the rat vas deferens and accessory male genital glands and that expression of these proteins are probably regulated by androgen hormones. In particular, expression of NGF and its receptor TrkA is increased in these organs after castration, thus suggesting a role for NGF in the apoptotic processes that regulate the involution of these organs under conditions of androgen deprivation.

\section{Acknowledgements}

The authors thank Mr. A. Calamo and Ms. S. Alí for their careful technical assistance.

\section{References}

Ahn JY, Kang $\mathrm{L}$, Kim HJ, Kang $\mathrm{H}$, Kim SH, Kim JY, et al. Induction method of tyrosine kinase A-mediated cell death in rat pheochromocytoma. Biotechnol Lett 2005;27:583-7.

Barbacid M. Neurotrophic factors and their receptors. Curr Opin Cell Biol 1995;7:148-55.

Cunha GR . Role of mesenchymal-epithelial interactions in normal and abnormal development of the mammary gland and prostate. Cancer 1994; 74:1030-44.

Dalal R, Djakiew D. Molecular characterization of neurotrophin expression and the corresponding tropomyosin receptor kinases (trks) in epithelial and stromal cells of the human prostate. Mol Cell Endocrinol 1997;134:15-22.

Djakiew D, Delsite R, Pflug B, Wrathall J, Lynch JH, Onoda M. Regulation of growth by a nerve growth factor-like protein which modulates paracrine interactions between a neoplastic epithelial cell line and stromal cells of the human prostate. Cancer Res 1991;51: 3304-10.

Djakiew D, Tarkington MA, Lynch JH. Paracrine stimulation of polarized secretion from monolayers of a neoplastic prostatic epithelial cell line by prostatic stromal cell proteins. Cancer Res 1990;50: 1966-74.

Ernfors P, LeeKF, Kucera J, Jaenisch R. Lack of neurotrophin-3 leads to deficiencies in the peripheral nervous system and loss of limb proprioceptive afferents. Cell 1994;77:503-12.

Geldof AA, Haarst EP van, Newling DWW. Neurotrophic factors in prostate and prostatic cancer. Prostate Cancer Prostatic Dis 1998; 1:236-24.

Graham CW, Lynch JH, Djakiew D. Distribution of nerve growth factor-like protein and nerve growth factor receptor in human prostatic hyperplasia and prostatic carcinoma. J Urol 1992;147:1444-7.

Guate JL, Fernandez N, Lanzas JM, Escaf S, Vega JA. Expression of p75 (LNGFR) and Trk neurotrophin receptors in normal and neoplastic human prostate. BJU Int 1999; 84: 495-502.

Harper GP, Barde YA, Burnstock G, Carstairs JR, Dennison ME, Suda $K$, Vernon CA. Guinea pig prostate is a rich source of nerve growth factor. Nature 1979;279: 160-2.

Harper GP, Glandville RW, Thoenen $\mathrm{H}$. The purification of nerve growth factor from bovine seminal plasma. J Biol Chem 1982;257: 85418.

Harper GP, Thoenen $\mathrm{H}$. The distribution of nerve growth factor in the male sex organs of mammals. J Neurochem 1980; 34: 893-903.

Hofmann HD, Unsicker K. Characterization and partial purification of a novel neuronotrophic factor from bovine seminal vesicle. J Neurochem 1987;48: 1425-33.

Huang EJ, Reichart LF. Neurotrophins: roles in neuronal development and function. Annu Rev Neurosci 2001;24:677-736

Huggett J, Dheda K, Bustin S, Zumla A. Real-time RT-PCR normalisation; strategies and considerations, Genes Immun 2005;6: 279-84.

Humpel C, Lindqvist $E$, Olson L. Detection of nerve growth factor $\mathrm{mRNA}$ in rodent salivary glands with digoxigenin- and 33P-labeled oligonucleotides: effects of castration and sympathectomy. J Histochem Cytochem 1993;41:703-708.

Jin W, Arai KY, Shimizu K, Kojima C, Itoh M, Watanabe G, Taya K. Cellular Localization of NGF and its Receptors trkA and p75LNGFR in Male Reproductive Organs of the Japanese Monkey, Macaca fuscata fuscata. Endocrine 2006;29:155-60.

Katoh-Semba R, Semba R, Kato H, Ueno M, Arakawa Y, Kato K. Regulation by androgen of levels of the beta subunit of nerve growth factor and its mRNA in selected regions of the mouse brain. J Neurochem 1994;62:2141-7.

Krüttgen A, Schneider I, Weis J. The dark side of the NGF family: neurotrophins in neoplasias Brain Pathol 2006; 16: 304-10.

Leon A, Buriani A, Dal Toso R, Fabris M, Romanello S, Aloe L, LeviMontalcini R. Mast cells synthesize, store, and release nerve growth factor. Proc Natl Acad Sci USA 1994;91:3739-43.

Levi-Montalcini $R$. The nerve growth factor 35 years later. Science 1987;237:1154-62.

Lewin GR, Barde YA Physiology of neurotrophins. Annu Rev Neurosci 1996;19:289-317.

Li CM, Watanabe G, Weng 0, Jin W, Furuta C, Suzuki AK, et al. Expression of Nerve Growth Factor (NGF), and Its Receptors TrkA and p75 in the Reproductive Organs of the Adult Male Rats. Zool Sci 2005;22:933-7.

Livak KJ and Schmittgen TD. Analysis of relative gene expression data using real-time quantitative $\mathrm{PCR}$ and the 2-[Delta][Delta]Ct method. Methods 2001;25:402-8.

MacGrogan D, Desprès G., Romand R, Dicou E. Expression of the beta-nerve growth factor gene in male sex organs of the mouse, rat, and guinea pig. J Neurosci Res 1991;28:567-73.

MacGrogan D, Saint-Andre JP, Dicou E. Expression of nerve growth factor and nerve growth factor receptor genes in human tissues and in prostatic adenocarcinoma cell lines. J Neurochem 1992;59: 1381-91.

Mirabella N, Squillacioti C, Paone I, Ciarcia R, Russo M, Paino G. Effects of castration on the expression of brain-derived neurotrophic factor (BDNF) in the vas deferens and male accessory genital glands of the rat. Cell Tissue Res 2006;323:513-22.

Mirabella N, Squillacioti C, De Luca A, Paino G. Effects of Castration on the Expression of TrkB and p75NTR in the Vas Deferens and Male Accessory Genital Glands of the Rat. Anat Histol Embryol 2008;37:118-25.

Muragaki Y, Chou TT, Kaplan DR, Trojanowski JQ, Lee VM. Nerve growth factor induces apoptosis in human medulloblastoma cell lines that express TrkA receptors. J Neurosci 1997; 17: 530-42.

Murer MG, Yan Q, Raisman-Vozari R. Brain-derived neurotrophic factor in the control human brain, and in Alzheimer's disease and Parkinson's disease. Prog Neurobiol 2001;63: 71-124. 


\section{Squillacioti et al.}

Nakagawara A, Arima-Nakagawara M, Scavarda NJ, Azar CG, Cantor $A B$, Brodeur GM. Association between high levels of expression of the TRK gene and favorable outcome in human neuroblastoma. N Engl J Med 1993; 328: 847-54.

Patapoutian A, Reichart LF. Trk receptors: mediators of neurotrophin action. Curr Opin Neurobiol 2001;11: 272-280.

Paul A, Habib F. Low-affinity nerve growth factor receptors (p75LNGFR) in human prostate tissue: stromal localisation. Urol Res 1998;26:111-6.

Paul AB, Grant ES, Habib FK. The expression and localisation of betanerve growth factor (beta-NGF) in benign and malignant human prostate tissue : relationshipp to neuroendocrine differentiation. $\mathrm{Br}$ J Cancer 1996;74:1990-6.

Pflug BR, Dionne C, Kaplan DR, Lynch J, Djakiew D. Expression of a Trk high affinity nerve growth factor receptor in the human prostate. Endocrinology 1995; 136: 262-8.

Rosenbaum T, Vidaltamayo $R$, Sanchez-Soto MC, Zentella A, Hiriart $M$. Pancreatic beta cells synthesize and secrete nerve growth factor. Proc Natl Acad Sci USA 1998;95: 784-8.

Sariola $\mathrm{H}$. The neurotrophic factors in non-neuronal tissues. Cell Mol Life Sci 2001;58:1061-6.

Shikata H, Utsumi N, Hiramatsu M, Minami N, Nemoto N, Shikata T.
Immunohistochemical localization of nerve growth factor and epidermal growth factor in guinea pig prostate gland. Histochemistry 1984;80:411-3.

Snider WD. Function of the neurotrophins during nervous system development: what the knockouts are teaching us. Cell 1994;77: 627-38.

Teng KK, Hempstead BL. Neurotrophins and their receptors: Signaling trios in complex biological systems. Cell Mol Life Sci 2004;61:3548.

Tessarollo $L$. Pleiotropic functions of neurotrophins in development. Cytokine Growth Factor Rev 1998; 9: 125-37.

Weeraratna AT, Arnold JT, George DJ, DeMarzo A, Isaacs JT. Rational basis for Trk inhibition therapy for prostate cancer. Prostate 2000; 45:140-8.

Yamamoto M, Sobue G, Yamamoto K, Terao S, Mitsuma T .Expression of mRNAs for neurotrophic factors (NGF, BDNF, NT-3 and GDNF) and their receptors ( $p 75 \mathrm{NGFR}$, trkA, trkB and trkC) in the adult human peripheral nervous system and nonneural tissues. Neurochem Res 1996; 1:929-38.

Yuan JS, Reed A, Chen F, Stewart CN. Statistical analysis of real-time PCR data. BMC Bioinformatics 2006;7:85. 